\title{
WSKAŹNIKI EFEKTYWNOŚCI ŚRODOWISKOWEJ UJMOWANE W SPRAWOZDAWCZOŚCI PRZEZ ORGANIZACJE ZAREJESTROWANE W SYSTEMIE EMAS
}

Organizacje, które chcą zmniejszać negatywne oddziaływanie na środowisko naturalne mogą wdrożyć w tym celu system zarządzania środowiskowego. Jednym z takich systemów jest System Ekozarządzania i Audytu (EMAS). System EMAS opiera się na wymaganiach normy ISO 14001, ale zawiera także klika dodatkowych wymagań, które muszą zostać spełnione przez organizacje chcące uzyskać rejestrację $\mathrm{w}$ tym systemie. Jedna $\mathrm{z}$ różnic dotyczy efektów działalności środowiskowej. System EMAS stawia większe wymagania w tym zakresie. Organizacje zarejestrowane w systemie EMAS muszą być w stanie wykazać ciągłą poprawę efektów swojej działalności środowiskowej. Jedną z form dokumentowania poprawy w tym zakresie są ujmowane w deklaracjach środowiskowych wskaźniki efektywności środowiskowej. Zgodnie z Rozporządzeniem EMAS, zadania wskaźników efektywności środowiskowej to między innymi przedstawienie dokładnej oceny efektów działalności środowiskowej organizacji oraz umożliwienie porównania poszczególnych lat w celu dokonania oceny rozwoju efektów działalności środowiskowej organizacji. Główne wskaźniki, które powinny zostać ujęte w deklaracji środowiskowej związane są z kluczowymi obszarami środowiskowymi i dotyczą: efektywności energetycznej, efektywnego wykorzystania materiałów, wody, odpadów, różnorodności biologicznej oraz emisji. Organizacje mają także możliwość ujmowania w deklaracjach dodatkowych wskaźników, jeżeli mają one znaczenie dla zidentyfikowanych przez organizację znaczących aspektów środowiskowych.

Celem artykułu było przedstawienie istoty wskaźników efektywności środowiskowej występujących w systemie EMAS oraz ich przegląd w deklaracjach środowiskowych polskich organizacji zarejestrowanych w tym systemie.

Badanie miało charakter pełny, analizie poddano deklaracje wszystkich polskich organizacji, zarejestrowanych w systemie EMAS 3 lutego 2014 r. Wyniki badań przedstawiono w formie tabelarycznej.

Słowa kluczowe: EMAS, wskaźniki efektywności środowiskowej, efekty działalności środowiskowej.

\section{WPROWADZENIE}

Organizacje, które chcą zmniejszać negatywne oddziaływanie na środowisko naturalne, wynikające $\mathrm{z}$ prowadzonej działalności, mogą wdrożyć w tym celu system zarządzania środowiskowego. Wśród najbardziej znanych sformalizowanych systemów zarządzania środowiskowego można wymienić system zarządzania środowiskowego

\footnotetext{
${ }^{1}$ Mgr Jadwiga Nycz - Wróbel, Politechnika Rzeszowska, Wydział Zarządzania, Katedra Systemów Zarządzania i Logistyki, 35-959 Rzeszów, ul. Powstańców Warszawy 6, tel:17 865 1802, e- mail: jadwiganw@prz.edu.pl
} 
zgodny z wymaganiami normy ISO 14001 oraz System Ekozarządzania i Audytu (EMAS). Te systemy zarządzania środowiskowego mają charakter dobrowolny, czyli są instrumentami, po które mogą, ale nie muszą sięgać organizacje zainteresowane prowadzeniem działań na rzecz ochrony środowiska. System EMAS opiera się na wymaganiach normy ISO 14001 (aby wdrożyć system EMAS, należy stosować m.in. wymagania normy ISO 14001), ale zawiera także klika dodatkowych wymagań, które muszą zostać spełnione przez organizacje chcące uzyskać rejestrację w tym systemie. Jedna z różnic dotyczy efektów działalności środowiskowej. System EMAS stawia większe wymagania w tym zakresie. Organizacje zarejestrowane w systemie EMAS muszą być w stanie wykazać ciagłą (rok po roku) poprawę efektów swojej działalności środowiskowej. Jedną z form dokumentowania poprawy w zakresie efektów działalności środowiskowej są ujmowane w deklaracjach środowiskowych wskaźniki efektywności środowiskowej.

Celem artykułu jest przedstawienie istoty wskaźników efektywności środowiskowej występujących w systemie EMAS oraz ich przegląd w deklaracjach środowiskowych polskich organizacji zarejestrowanych w tym systemie. Analizie poddano deklaracje wszystkich polskich organizacji zarejestrowanych w systemie EMAS 3 lutego 2014 r.

\section{WYMOGI SYSTEMU EMAS W ODNIESIENIU DO EFEKTÓW DZIALALNOŚCI ŚRODOWISKOWEJ ORGANIZACJI}

System Ekozarządzania i Audytu (EMAS) jest instrumentem zarządzania o dobrowolnym charakterze, wprowadzonym przez Unię Europejską. Może zostać wdrożony przez organizacje z państw Unii Europejskiej oraz spoza Wspólnoty. System EMAS „ma na celu działanie na rzecz zrównoważonej konsumpcji i produkcji oraz zrównoważonej polityki przemysłowej. Jego celem jest także wspieranie ciągłej poprawy efektów działalności środowiskowej organizacji poprzez ustanowienie i wdrażanie przez organizacje systemów zarządzania środowiskowego oraz systematyczną, obiektywną i okresową ocenę efektywności takich systemów, dostarczanie informacji o efektach działalności środowiskowej, prowadzenie otwartego dialogu ze społeczeństwem i innymi zainteresowanymi stronami oraz aktywne zaangażowanie pracowników organizacji"2. Organizacje, które chcą przystapić do systemu EMAS, muszą spełniać wszystkie wymogi tego systemu (określone w Rozporządzeniu EMAS), w tym także spełnienie wymogu ciągłej poprawy efektów działalności środowiskowej. Rozporządzenie EMAS definiuje efekty działalności środowiskowej jako ,wymierne wyniki zarządzania przez organizację swoimi aspektami środowiskowymi”3. Aspekty środowiskowe są natomiast definiowane, jako „składnik działalności, produktów lub usług organizacji, które wpływają lub mogą wpływać na środowisko",4.

Kolejnym wymogiem Rozporządzenia EMAS, istotnie odróżniającym ten system od innych systemów zarządzania środowiskowego, jest wymóg publikowania deklaracji środowiskowej. W niej zarejestrowane w systemie organizacje mają obowiązek zamieszczać między innymi informacje na temat efektów swojej działalności środowiskowej. Załącznik IV Rozporządzenia EMAS zawiera wymagania, aby w

\footnotetext{
${ }^{2}$ Rozporzadzenie Parlamentu Europejskiego i Rady (WE) nr 1221/2009, s. 4.

3 Ibidem.

${ }^{4}$ Ibidem.
} 
sprawozdawczości zawrzeć m.in. „streszczenie dostępnych danych, dotyczących efektów działalności środowiskowej organizacji w porównaniu $\mathrm{z}$ jej celami i zadaniami środowiskowymi, w odniesieniu do znaczącego wpływu organizacji na środowisko. Sprawozdawczość obejmuje główne wskaźniki i inne istniejące wskaźniki efektywności środowiskowej określone w Rozporządzeniu",5.

Deklaracje środowiskowe są publicznie dostępne. Zainteresowane strony mają możliwość poprzez ich analizę (a konkretnie analizę zawartych w nich informacji, dotyczących wskaźników efektywności środowiskowej) uzyskać informacje między innymi na temat oddziaływania organizacji na środowisko i rozwoju efektów jej działalności środowiskowej. Zgodnie z Rozporządzeniem EMAS zadaniem wskaźników efektywności środowiskowej jest między innymi przedstawienie dokładnej oceny efektów działalności środowiskowej organizacji oraz umożliwienie porównania poszczególnych lat w celu dokonania oceny rozwoju efektów działalności środowiskowej organizacji. Wskaźniki powinny być zrozumiałe i jednoznaczne. Powinny także umożliwić porównanie uzyskanych efektów działalności środowiskowej z wymaganiami prawnymi lub innymi dokumentami, stanowiącymi punkt odniesienia (takimi jak sektorowe dokumenty referencyjne) ${ }^{6}$. Rozporządzenie EMAS wymienia główne wskaźniki, które powinny zostać ujęte w deklaracji środowiskowej. Mają one zastosowanie do wszystkich typów organizacji i dotyczą następujących obszarów środowiskowych (określanych jako kluczowe):

- efektywność energetyczna;

- efektywne wykorzystanie materiałów;

- woda;

- odpady;

- różnorodność biologiczna;

- emisje $^{7}$.

Organizacje moga nie zamieszczać wszystkich wskaźników w deklaracji środowiskowej tylko w uzasadnionych przypadkach, gdy dany wskaźnik nie ma znaczenia dla istotnych, bezpośrednich aspektów środowiskowych, zidentyfikowanych przez organizację.

Rozporządzenie EMAS jednoznacznie definiuje, czego dotyczą poszczególne, główne wskaźniki.

W wypadku wskaźnika dotyczącego efektywności energetycznej, przedstawiając całkowity roczny wkład/wpływ w danym obszarze (oznaczany literą A), organizacje wykazują:

- w odniesieniu do „całkowitego bezpośredniego zużycia energii” - całkowite roczne zużycie energii wyrażone w MWh lub GJ;

- w odniesieniu do „całkowitego zużycia energii odnawialnej” - procent całkowitego rocznego zużycia energii (elektrycznej oraz ciepła), wytworzonego przez organizację z odnawialnych źródeł energii ${ }^{8}$.

\footnotetext{
5 Ibidem, s. 36

6 Ibidem, s. 37.

${ }^{7}$ Ibidem.

${ }^{8}$ Ibidem.
} 
W obszarze środowiskowym, dotyczącym efektywnego wykorzystania materiałów, organizacje wykazują roczny przepływ masy różnych, używanych przez organizację materiałów wyrażony w tonach (z wyjątkiem energii i wody $)^{9}$.

W wypadku wody organizacje wykazują całkowite roczne zużycie wody (wyrażone w $\left.\mathrm{m}^{3}\right)^{10}$. W wypadku odpadów organizacje wykazują całkowita, roczną ilość wytwarzanych odpadów (z podziałem na typy), wyrażoną w tonach oraz całkowita, roczną ilość wytwarzanych odpadów niebezpiecznych, wyrażonych w kilogramach lub tonach $^{11}$. W obszarze środowiskowym, dotyczącym różnorodności biologicznej, organizacje wykazują użytkowanie gruntów w terenie zabudowanym (wyrażone $\left.\mathrm{w} \mathrm{m}^{2}\right)^{12}$. W wypadku emisji natomiast organizacje wykazują:

- całkowitą, roczną emisję gazów cieplarnianych, wyrażoną w tonach ekwiwalentu $\mathrm{CO}^{2}$

- całkowita, roczną emisję do powietrza, wyrażoną w kilogramach lub tonach ${ }^{13}$.

System EMAS pomaga organizacjom, które go wdrożyły, uzyskać trwałą poprawę w zakresie efektów działalności środowiskowej. Zarejestrowane organizacje mają obowiązek co roku przedstawiać informacje dotyczące efektów swojej działalności środowiskowej. Deklaracje środowiskowe (w których zamieszczanie są m.in. wartości wskaźników efektywności środowiskowej z poszczególnych lat) stanowią formę dialogu z osobami zainteresowanymi działalnością środowiskową organizacji. Dzięki wymogowi sprawozdawczości środowiskowej organizacje uczestniczące w tym systemie na bieżąco monitorują swoją działalność środowiskową, rozwój w tym zakresie oraz przyczyny ewentualnego braku poprawy w danym obszarze środowiskowym. Zdarzają się uzasadnione sytuacje, w których wartość wskaźników w stosunku do poprzedniego roku wzrasta, co może być spowodowane na przykład wzrostem wielkości produkcji w danym roku, dłuższym sezonem grzewczym, rozwojem działalności itp. Niemniej jednak organizacje dążą do tego, aby w dłuższym czasie być w stanie wykazać tendencję spadku wartości wskaźników, dotyczących kluczowych obszarów działalności środowiskowej.

\section{CHARAKTERYSTYKA ORGANIZACJI ZAREJESTROWANYCH W SYSTEMIE EMAS W POLSCE (OBJĘTYCH BADANIEM)}

W Polsce 3 lutego 2014 r. w systemie EMAS zarejestrowane były 43 organizacje. Wykaz organizacji aktualnie zarejestrowanych w systemie EMAS w Polsce przedstawiono w tabeli 1.

Działalność prowadzona przez organizacje zarejestrowane w systemie EMAS klasyfikowana jest zgodnie ze statystyczną klasyfikacją działalności gospodarczej Wspólnoty Europejskiej - NACE [Rozporządzenie (WE) nr 1893/2006 Parlamentu Europejskiego i Rady z 20 grudnia 2006 r.]. Zgodnie z tą klasyfikacją polskie organizacje zarejestrowane w systemie EMAS prowadzą następujące rodzaje działalności:

- $27,91 \%$ - działalność produkcyjna;

\footnotetext{
${ }^{9}$ Ibidem.

${ }^{10}$ Ibidem.

11 Ibidem.

12 Ibidem, s. 38.

13 Ibidem, s. 37.
} 
Wskaźniki efektywności...

- 13,95\% - działalność związana z wytwarzaniem energii elektrycznej (NACE $35.11)$

- 11,63\% - działalność związana ze zbieraniem odpadów innych niż niebezpieczne (NACE 38.11); 60\%, wśród tych organizacji zajmuje się także zbieraniem odpadów niebezpiecznych (NACE 38.12);

- 9,3\% - działalność związana z rekultywacją i pozostałymi usługami, związanymi z gospodarką odpadami (NACE 38.32);

- 9,3\% - działalność związana z poborem, uzdatnianiem i dostarczaniem wody i/lub odprowadzaniem i oczyszczaniem ścieków;

- 6,98\% - działalność związana $\mathrm{z}$ kierowaniem podstawowymi rodzajami działalności publicznej (NACE 84.11);

- 4,65\% - działalność szpitali (NACE 86.10);

- wśród pozostałych $16,28 \%$ organizacji, każda prowadzi inny rodzaj działalności.

Tabela 1. Organizacje aktualnie zarejestrowane w systemie EMAS w Polsce

\begin{tabular}{|c|c|}
\hline Lp. & ORGANIZACJA \\
\hline 1. & entrum Onkologii im. prof. F. Łukaszczyka - BYDGOSZCZ \\
\hline 2. & Przedsiębiorstwo Budowy Dróg i Mostów Sp. z o.o. - MIŃSK MAZOWIECKI \\
\hline 3. & RAFAKO S.A. - RACIBÓRZ \\
\hline 4. & $\begin{array}{l}\text { Wojewódzki Fundusz Ochrony Środowiska i Gospodarki Wodnej w Katowicach - } \\
\text { KATOWICE }\end{array}$ \\
\hline 5. & Bombardier Transportation Polska Spółka z o.o. - WROCŁAW \\
\hline 6. & Dolina Nidy Sp. z o.o. - PIŃCZÓW \\
\hline 7. & $\begin{array}{l}\text { Urząd Miasta w Trzebini (Wydział Gospodarki Ochrony środowiska Rolnictwa } \\
\text { i Leśnictwa) - TRZEBINIA }\end{array}$ \\
\hline 8. & $\begin{array}{l}\text { TAURON Wytwarzanie S.A., Oddział Elektrownia Łaziska w Łaziskach Górnych - } \\
\text { ŁAZISKA GÓRNE }\end{array}$ \\
\hline 9. & EDF Wybrzeże S.A - GDAŃSK \\
\hline 10. & $\begin{array}{llllll}\text { Przedsiębiorstwo Wodociagów i Kanalizacji } & \text { Okręgu Częstochowskiego } & \text { S.A. } \\
\text { CZĘSTOCHOWA } & & & & \\
\end{array}$ \\
\hline 11. & Arctic Paper Kostrzyn S.A. - KOSTRZYN NAD ODRĄ \\
\hline 12. & $\begin{array}{l}\text { Międzygminne Przedsiębiorstwo Gospodarki Odpadami i Energetyki Odnawialnej } \\
\text { „MASTER” Sp. z o.o. - TYCHY }\end{array}$ \\
\hline 13. & CHNOLOGY Sp. z o.o. spółka komandytowo-akcyjna - DOBCZYCE \\
\hline 14. & $\begin{array}{l}\text { PGE Górnictwo i Energetyka Konwencjonalna S.A., Oddział Zespół Elektrowni Dolna } \\
\text { Odra - NOWE CZARNOWO }\end{array}$ \\
\hline 15. & owskie Przedsiębiorstwo Komunalne Sp. z o.o. - CZĘSTOCHOWA \\
\hline 16. & Przedsiębiorstwo Gospodarki Wodnej i Rekultywacji S.A. - JASTRZĘBIE ZDRÓJ \\
\hline 17. & Regionalne Centrum Gospodarki Wodno-Ściekowej - TYCHY \\
\hline 18. & $\begin{array}{l}\text { TAURON Wytwarzanie S.A., Oddział Elektrownia Jaworzno III w Jaworznie - } \\
\text { JAWORZNO }\end{array}$ \\
\hline 19. & KOBA Organizacja Odzysku S.A. - KRAKÓW \\
\hline 20. & $\begin{array}{l}\text { TAURON Wytwarzanie Spółka Akcyjna-Oddział Elektrownia Siersza w Trzebini - } \\
\text { TRZEBINIA }\end{array}$ \\
\hline 21. & nia Warta S.A. - DZIAŁOSZYN \\
\hline 22. & emia-Blachownia S.A. - KĘDZIERZYN-KOŹLE \\
\hline 23. & Przedsiębiorstwo Produkcji Kruszywa i Usług Geologiczr \\
\hline
\end{tabular}




\begin{tabular}{|l|l|}
\hline & RZESZÓW \\
\hline 24. & CEMEX sp. z o.o. - CHEŁM \\
\hline 25. & Ministerstwo Środowiska - WARSZAWA \\
\hline 26. & MAN Trucks Sp. z o.o. - NIEPOŁOMICE \\
\hline 27. & AB S.A. - WROCŁAW \\
\hline 28. & Miejskie Przedsiębiorstwo Wodociagów i Kanalizacji w Lublinie Sp. z o.o. - LUBLIN \\
\hline 29. & JAGO-PRO Sp. z o.o. - JAWORZNO \\
\hline 30. & Urząd Miejski Wrocławia - WROCŁAW \\
\hline 31. & $\begin{array}{l}\text { TAURON Wytwarzanie S.A., Oddział Zespół Elektrociepłowni Bielsko-Biała - } \\
\text { BIELSKO-BIAŁA }\end{array}$ \\
\hline 32. & ALBA MPGK Sp. z o.o. - DĄBROWA GÓRNICZA \\
\hline 33. & DOL-EKO Organizacja Odzysku S.A. - WROCŁAW \\
\hline 34. & TOM Organizacja Odzysku S.A. - SZCZECIN \\
\hline 35. & Organizacja Odzysku Odpadów i Opakowań „EKOLA” S.A. - GDAŃSK \\
\hline 36. & PONAR WADOWICE S.A. - WADOWICE \\
\hline 37. & $\begin{array}{l}\text { Ośrodek Główny Instytutu Meteorologii i Gospodarki Wodnej Państwowego Instytutu } \\
\text { Badawczego }\end{array}$ \\
\hline 38. & ALBA Południe Polska Sp. z o.o. - DĄBROWA GÓRNICZA \\
\hline 39. & Zachodniopomorskie Centrum Onkologii - SZCZECIN \\
\hline 40. & Zakład Utylizacji Odpadów Sp. z o.o. - GORZÓW WIELKOPOLSKI \\
\hline 41. & Przedsiębiorstwo „LABTAR” Sp. z o.o. - TARNÓW OPOLSKI \\
\hline 42. & TAURON Wytwarzanie Spółka Akcyjna, Oddział Elektrownia Łagisza - BĘDZIN \\
\hline 43. & H\&M HENNES \& MAURITZ LOGISTICS Sp. z o.o. - GĄDKI \\
\hline Źródło: opracowanie własne na podstawie www.gdos.gov.pl. \\
\hline
\end{tabular}

Źródło: opracowanie własne na podstawie www.gdos.gov.pl.

\section{PRZEGLĄD WSKAŹNIKÓW EFEKTYWNOŚCI ŚRODOWISKOWEJ UJMOWANYCH W DEKLARACJACH ŚRODOWISKOWYCH PRZEZ BADANE ORGANIZACJE}

$\mathrm{Na}$ wstępie dokonano przeglądu głównych wskaźników efektywności środowiskowej, ujętych $w$ deklaracjach środowiskowych przez organizacje zarejestrowane w systemie EMAS.

Rozporządzenie EMAS wymaga przedstawienia w deklaracji środowiskowej głównych wskaźników, dotyczących kluczowych obszarów środowiskowych, takich jak: zużycie energii elektrycznej, efektywne wykorzystanie materiałów, zużycie wody, ilość wytworzonych odpadów, powierzchnia użytkowanego terenu (różnorodność biologiczna) oraz emisje (gazów cieplarnianych i emisje do powietrza przynajmniej $\mathrm{SO}_{2}, \mathrm{NO}_{\mathrm{x}}, \mathrm{PM}$ ). Organizacje mogą także ująć w deklaracjach środowiskowych dodatkowe wskaźniki efektywności środowiskowej, jeżeli uważają je za mające znaczenie dla ich znaczących aspektów środowiskowych. W uzasadnionych wypadkach organizacje mogą także nie uwzględniać w sprawozdawczości wszystkich głównych wskaźników efektywności środowiskowej, jeżeli uznają że nie mają one znaczenia dla ich znaczących aspektów środowiskowych.

Główne wskaźniki efektywności środowiskowej ujęte w deklaracjach środowiskowych przez polskie organizacje zarejestrowane w systemie EMAS przedstawiono w tabeli 2 . 
Wskaźniki efektywności...

Tabela 2. Główne wskaźniki efektywności środowiskowej ujęte w deklaracjach środowiskowych przez polskie organizacje zarejestrowane w systemie EMAS

\begin{tabular}{|l|c|}
\hline \multicolumn{1}{|c|}{ Główne wskaźniki efektywności środowiskowej } & $\begin{array}{c}\text { Organizacje, które ujęły } \\
\text { wskaźnik } \\
\text { w deklaracji } \\
\text { środowiskowej (\%) }\end{array}$ \\
\hline EFEKTYWNOŚĆ ENERGETYCZNA & 86,04 \\
\hline EFEKTYWNE WYKORZYSTANIE MATERIAŁÓW & 67,44 \\
\hline WODA & 88,37 \\
\hline ODPADY & 90,7 \\
\hline RÓŻNORODNOŚĆ BIOLOGICZNA & 58,13 \\
\hline EMISJE & 83,72 \\
\hline
\end{tabular}

Źródło: opracowanie własne na podstawie deklaracji środowiskowych, dostępnych na stronie www.gdos.gov.pl.

Główne wskaźniki efektywności środowiskowej ujęte w sprawozdawczości przez największą liczbę polskich organizacji zarejestrowanych w systemie EMAS dotyczyły: wytwarzania odpadów $(90,7 \%)$, zużycia wody $(88,37 \%)$, efektywności energetycznej $(86,04 \%)$ oraz emisji $(83,72 \%)$. Wskaźnik dotyczący efektywnego wykorzystania materiałów zaznaczyło w swojej deklaracji środowiskowej 67,44\% wszystkich organizacji. Wskaźnik dotyczący różnorodności biologicznej natomiast uwzględniło w deklaracji 58,13\% organizacji, zarejestrowanych w systemie EMAS.

Rozporządzanie EMAS dopuszcza (w uzasadnionych przypadkach) możliwość nieujmowania w sprawozdawczości jednego lub większej liczby głównych wskaźników efektywności środowiskowej. Organizacje, które nie uwzględniły poszczególnych wskaźników w swojej deklaracji środowiskowej, uzasadniają to brakiem ich znaczenia dla znaczących aspektów środowiskowych lub brakiem zastosowania w przypadku prowadzonej przez nie działalności. Wśród organizacji objętych badaniem były także takie, które nie ujęły w sprawozdawczości żadnego z głównych wskaźników efektywności środowiskowej wymaganych przez rozporządzenie EMAS (stanowiły one 9,3\% wszystkich organizacji zarejestrowanych w systemie EMAS). Uzasadnione to było rodzajem działalności prowadzonej przez te organizacje.

Rozporządzenie EMAS dopuszcza także możliwość uwzględniania w sprawozdawczości dodatkowych wskaźników efektywności środowiskowej, jeżeli mają one znaczenie dla działalności organizacji. $\mathrm{W}$ artykule dokonano przeglądu dodatkowych wskaźników, które zostały wymienione w deklaracjach środowiskowych organizacji zarejestrowanych w systemie EMAS (tab. 3).

Z przeglądu wynika, że wśród dodatkowych wskaźników ujętych w sprawozdawczości przez ponad $20 \%$ organizacji zarejestrowanych w systemie EMAS można wymienić wskaźniki dotyczące: ilości wytwarzanych ścieków (42\%), produkcji energii ze źródeł odnawialnych $(23,3 \%)$ oraz recyklingu odpadów (21\%). Wśród organizacji, objętych badaniem $14 \%$ wymieniło w sprawozdawczości wskaźnik dotyczący prowadzonych akcji ekologiczno-edukacyjnych. Wśród wszystkich polskich organizacji zarejestrowanych $\mathrm{w}$ systemie EMAS 9,3\% z nich ujęło $\mathrm{w}$ deklaracjach wskaźniki dotyczące: emisji hałasu, prowadzonej edukacji/szkoleń oraz przyrostu liczby klientów w zakresie przejęcia obowiązków odzysku i recyklingu. W deklaracjach środowiskowych $7 \%$ organizacji objętych badaniem wskazało na wskaźnik dotyczący ilości odpadów 
zebranych do odzysku.

Tabela 3. Dodatkowe wskaźniki ujęte w deklaracjach środowiskowych przez polskie organizacje, zarejestrowane w systemie EMAS

\begin{tabular}{|l|c|}
\hline \multicolumn{1}{|c|}{ Dodatkowe wskaźniki } & $\begin{array}{c}\text { Organizacje, które } \\
\text { ujęły wskaźnik } \\
\text { w deklaracji } \\
\text { środowiskowej (\%) }\end{array}$ \\
\hline WYTWARZANIE ŚCIEKÓW & 42 \\
\hline PRODUKCJA ENERGII ZE ŹRÓDEŁ ODNAWIALNYCH & 23,3 \\
\hline RECYKLING ODPADÓW & 21 \\
\hline AKCJE EKOLOGICZNO-EDUKACYJNE & 14 \\
\hline EMISJA HAŁASU & 9,3 \\
\hline $\begin{array}{l}\text { PRZYROST LICZBY KLIENTÓW W ZAKRESIE PRZEJECIA } \\
\text { OBOWIAZKÓW ODZYSKU I RECYKLING }\end{array}$ & 9,3 \\
\hline EDUKACJA/SZKOLENIA & 9,3 \\
\hline ODPADY ZEBRANE DO ODZYSKU & 7 \\
\hline EMISJE DO WODY & 2,33 \\
\hline SPRZEDAŻ SUROWCÓW WTÓRNYCH & 2,33 \\
\hline
\end{tabular}

Źródło: opracowanie własne na podstawie deklaracji środowiskowych, dostępnych na stronie www.gdos.gov.pl.

Wśród dodatkowych wskaźników ujmowanych w sprawozdawczości przez badane organizacje znalazły się także między innymi wskaźniki dotyczące: emisji do wody $(2,33 \%)$ oraz sprzedaży surowców wtórnych $(2,33 \%)$.

Warto podkreślić, że przegląd wskaźników nie był zadaniem łatwym ze względu na różny sposób ich prezentacji w deklaracjach środowiskowych. Wprawdzie Rozporządzenie EMAS III określiło, jakie informacje w zakresie wymaganych wskaźników efektywności środowiskowej należy ująć w deklaracjach środowiskowych, ale forma ich prezentacji w deklaracjach jest nadal bardzo różna. Część organizacji prezentuje wskaźniki efektywności środowiskowej w formie tabelarycznej (jedna zbiorcza tabela), część organizacji w postaci osobnych tabel dla poszczególnych wskaźników, jeszcze inne organizacje w formie wykresów lub w formie zarówno tabelarycznej, jak i na wykresach. Różnice dotyczą także okresów czasowych, w jakich organizacje prezentują wskaźniki. Uwagi dotyczące trudności w porównywaniu i analizowaniu deklaracji środowiskowych zawarto także $\mathrm{w}$ badaniach, przeprowadzonych wśród fińskich organizacji, zarejestrowanych w systemie EMAS ${ }^{14}$, a także w badaniu Evaluation of EMAS and Eco-Label for their Revision, Report 2: Research Findings (EVER) ${ }^{15}$

Wskaźniki efektywności środowiskowej mają na celu między innymi umożliwienie porównania kolejnych lat działalności organizacji w celu oceny rozwoju efektów jej działalności środowiskowej. ${ }^{16}$ Analiza poszczególnych lat powinna wykazać zmniejszanie

\footnotetext{
${ }^{14}$ S. Erkko, M. Melanen, P. Mickwitz, Eco-efficiency in the Finnish EMAS reports - a buzz world?, ,Journal of Cleaner Production" 2005/13, s. 802-803.

${ }^{15}$ EVER: Evaluation of EMAS and Eco-Label for their Revision. Report 2: Research Findings, 26 December 2005, s. 7.

${ }^{16}$ Przykład takiego zestawienia w: P. Pachura, A. Ociepa-Kubicka, Eco-Management and Audit Scheme (EMAS) functioning on the example of the Water Supply and Sewerage Joint Stock Company of the Czestochowa District, Polish Journal of Management Studies 2014, Vol.10, No 2,
} 
się wartości wskaźników w stosunku do lat poprzednich w odniesieniu do kluczowych obszarów działalności oraz zwiększenie wartości wskaźników w odniesieniu do obszarów działalności, związanych z na przykład recyklingiem odpadów, wytwarzaniem energii ze źródeł odnawialnych lub prowadzeniem akcji ekologiczno-edukacyjnych. Wskaźniki ujmowane w deklaracjach środowiskowych umożliwiają także porównanie ich wartości, w stosunku do limitów i pozwoleń, zawartych w przepisach środowiskowych, dotyczących działalności organizacji (których - zgodnie z wymogiem rozporządzenia EMAS - muszą bezwzględnie przestrzegać). System EMAS stawia organizacjom wymóg ciagłego (rok po roku) zmniejszania ich negatywnego oddziaływania na środowisko. I właśnie między innymi analiza wartości wskaźników efektywności środowiskowej jest dla organizacji źródłem informacji o efektach prowadzonej działalności środowiskowej.

Przegląd wskaźników badanych organizacji pozwolił na wysunięcie wniosków, że organizacje nie zawsze były w stanie wykazać zmniejszanie wartości głównych wskaźników w każdym kolejnym roku. Zdarzały się sytuacje, w których wartość wskaźnika w stosunku do roku poprzedniego zwiększyła się. Warto jednak podkreślić, że organizacje w każdym takim wypadku zamieszczały w deklaracji wytłumaczenie, co było powodem zwiększenia się wartości wskaźnika w danym roku.

Analizując jednak dłuższy przedział czasowy, można było zaobserwować tendencję do zmniejszania się wartości poszczególnych wskaźników dotyczących kluczowych obszarów działalności środowiskowej. Jest to dowód na to, że system EMAS może wpływać na poprawę w zakresie efektów działalności środowiskowej organizacji.

Warto w tym miejscu podkreślić, że chęć zmniejszania negatywnego oddziaływania organizacji na środowisko była jednym $\mathrm{Z}$ motywów wdrożenia systemu EMAS, wymienianym przez organizacje w różnych badaniach dotyczących systemu EMAS. Piszą o tym między innymi Emilsson, Hjelm ${ }^{17}$, a także Morrow, Rondinelli ${ }^{18}$. Można znaleźć informację o tym także w badaniu EVER ${ }^{19}$.

W badaniach literaturowych znajdujemy także dowody na wpływ systemu EMAS na poprawę w zakresie efektów działalności środowiskowej, zwłaszcza w obszarach dotyczących zużycia energii, wody i wykorzystania zasobów. Piszą o tym między innymi Emilsson, Hjelm ${ }^{20}$. Można o tym przeczytać także $\mathrm{w}$ badaniach $\mathrm{EVER}^{21}$ oraz Final Report. Study on the Costs and Benefis of EMAS to Registered Organisations ${ }^{22}$.

\footnotetext{
s.147.

17 Emilsson S., Hjelm O., Implementation of standardised environmental management systems in Swedish local authorities: reasons, expectations and some outcomes, „Environmental Science \& Policy” 2002/5, s. 445.

18 Morrow D., Rondinelli D., Adopting Corporate Environmental Management Systems: Motivations and Results of ISO 14001 and EMAS Certification, ,European Management Journal” 20/2 (2002), s. 166.

19 EVER: Evaluation of EMAS and Eco-Label..., s. 31.

${ }^{20}$ Emilsson S., Hjelm O., op. cit., s. 446.

${ }^{21}$ EVER: Evaluation of EMAS and Eco-Label..., s. 8.

22 Final Report. Study on the Costs and Benefis of EMAS to Registered Organisations, Milieu Ltd and Pisk and Policy Analysis Ltd for DG Environment of the European Commission under Study Contract No. 07.0307/2008/517800/ETU/G.2, October 2009, s. 92.
} 


\section{WNIOSKI}

Główne wskaźniki efektywności środowiskowej, ujęte w sprawozdawczości przez największą liczbę polskich organizacji zarejestrowanych w systemie EMAS, dotyczyły: wytwarzania odpadów, zużycia wody, efektywności energetycznej oraz emisji.

Dodatkowe wskaźniki, wymienione w sprawozdawczości przez największą liczbę badanych organizacji, dotyczyły: ścieków; produkcji energii ze źródeł odnawialnych, a także recyklingu odpadów. Inne dodatkowe wskaźniki zamieszczone w sprawozdawczości przez badane organizacje dotyczyły także między innymi: prowadzonych akcji ekologiczno-edukacyjnych; emisji hałasu; przyrostu liczby klientów w zakresie przejęcia obowiązków odzysku i recyklingu oraz ilości odpadów zebranych do odzysku.

$\mathrm{Na}$ podstawie przeglądu wskaźników ujętych w sprawozdawczości przez badane organizacje stwierdzono, że organizacje nie zawsze były w stanie wykazać zmniejszania wartości głównych wskaźników w każdym kolejnym roku. Analizując jednak dłuższy przedział czasowy, można było zaobserwować tendencję do zmniejszania się wartości poszczególnych wskaźników dotyczących kluczowych obszarów działalności środowiskowej. Jest to dowód na to, że system EMAS może się przyczyniać do poprawy w zakresie efektów prowadzonej przez organizację działalności środowiskowej.

\section{LITERATURA}

[1] Deklaracje środowiskowe organizacji zarejestrowanych $w$ systemie EMAS, www.gdos.gov.pl.

[2] Emilsson S., Hjelm O., Implementation of standardised environmental management systems in Swedish local authorities: reasons, expectations and some outcomes, ,Environmental Science \& Policy” 2002/5, s. 445-446.

[3] Erkko S., Melanen M., Mickwitz P., Eco-efficiency in the Finnish EMAS reports - a buzz world?, „Journal of Cleaner Production” 2005/13, s. 802-803.

[4] EVER: Evaluation of EMAS and Eco-Label for their Revision. Report 2: Research Findings, 26 December 2005, s. 7, 31.

[5] Final Report. Study on the Costs and Benefis of EMAS to Registered Organisations, Milieu Ltd and Pisk and Policy Analysis Ltd for DG Environment of the European Commission under Study Contract No. 07.0307/2008/517800/ETU/G.2, October 2009, s. 92.

[6] Morrow D., Rondinelli D., Adopting Corporate Environmental Management Systems: Motivations and Results of ISO 14001 and EMAS Certification, „European Management Journal” 20/2 (2002), s. 166.

[7] Pachura P., Ociepa-Kubicka A., Eco-Management and Audit Scheme (EMAS) functioning on the example of the Water Supply and Sewerage Joint Stock Company of the Czestochowa District, Polish Journal of Management Studies 2014, Vol.10, No 2.

[8] Rozporządzenie Parlamentu Europejskiego i Rady (WE) NR 1221/2009 z 25 listopada 2009 r. w sprawie dobrowolnego udziału organizacji w systemie ekozarządzania i audytu we Wspólnocie (EMAS), uchylające rozporządzenie (WE) nr 761/2001 oraz decyzje Komisji 2001/681/WE i 2006/193/WE. 


\section{ENVIRONMENTAL EFFICIENCY INDICATORS INCLUDED IN THE}

REPORTING BY ORGANIZATIONS REGISTERED UNDER EMAS

Organizations that want to reduce the negative impact on the environment can implement for this purpose an environmental management system. One of such system is the Eco-Management and Audit Scheme (EMAS). EMAS is based on the requirements of ISO 14001, but it also includes several additional requirements that must be met by organizations wishing to obtain registration in the system. One difference relates to environmental performance. EMAS places higher demands in this regard. Organizations registered in the EMAS system must be able to demonstrate a continuous improvement of its environmental performance. One of the forms documenting improvement in this area are environmental performance indicators included in the environmental statement. In accordance with the EMAS Regulation, the task of environmental performance indicators is e.g.: present a thorough evaluation of the environmental performance of the organization and to enable comparisons between years in order to assess the development of the environmental performance of the organization. The main indicators that should be included in the environmental statement are related to key environmental areas and concern: energy efficiency, efficient use of materials, water, waste, biodiversity and emissions. Organizations can also include in the declaration additional indicators if they are relevant to the organization's identified significant environmental aspects. The purpose of the article was to present the essence of environmental performance indicators occurring in EMAS and their review in the environmental statements of Polish organizations registered in the system. The study concerned all polish organizations registered under EMAS on 3.02.2014. The results are presented in tabular form.

Keywords: EMAS environmental performance indicators, environmental performance.

DOI:10.7862/rz.2014.hss.62

Przesłano do redakcji: kwiecień 2014

Przyjęto do druku: grudzień 2015 